\title{
FIRE INSULATION OF ALUMINUM GLAZED PARTITIONS DEPENDING ON THE INFILL SOLUTION OF FRAMEWORK PROFILES
}

\author{
Bartłomiej SĘDŁAK ${ }^{1}$, Paweł ROSZKOWSKI, Paweł SULIK \\ Instytut Techniki Budowlanej, Warszawa, Poland
}

\begin{abstract}
This paper presents the main problems related to the fire resistance of aluminium glazed partitions. It discusses technical solutions used in partition systems with a specific fire resistance class, as well as a procedure and the general principles of classification of fire resistance for structures of this type. Moreover, the paper presents the comparison of fire resistance test results of glazed partition test specimens, depending on the volume of insulation inserts placed inside the aluminium structure profiles. To made the comparison the specimens with the same transom - mullion structure were tested with two filling solutions - with same profiles filled only in the middle part and fully filled.
\end{abstract}

Keywords: glazed partition, aluminium profile, insulation insert, fire resistance, fire integrity, fire insulation

\section{INTRODUCTION}

The partition is a kind of inner wall of a building. It does not constitute a part of the building structure and thus is not designed to be subjected to any loads other than its own weight and those related with the conditions of its use. However, because it separates rooms within the building, it should meet certain requirements for soundproofing and fire resistance.

According to the regulations of many European Union countries in case of buildings for a specific purpose, e.g., hospitals, hotels or those with significant

\footnotetext{
${ }^{1}$ Corresponding author: Instytut Techniki Budowlanej, Zakład Badań Ogniowych, Filtrowa st 1, 00-611 Warszawa, Poland, e-mail:b.sedlak@itb.pl, tel.+48225664494
} 
height [1]-[3] partition walls as a non-load bearing elements of building should be designed and constructed in such a way that in case of fire it will limit the spread of fire and smoke in the building, allow the evacuation of users and ensure the safety of rescue team. Therefore, in this type of buildings partition walls shall fulfill the requirements of fire resistance.

\section{TECHNICAL SOLUTIONS}

Partition walls with specific fire resistance class are performed frequently as a wall light construction stiffened with steel or wood frame, eg. made of plasterboards [4], [5] or chipboards [6], [7], walls built of lightweight smallelements [8]-[10], or made of sandwich panels [11]-14]. These materials, however, despite its excellent properties allowing to stop the fire are aesthetically and increasingly they are being replaced by far better-looking transparent elements (glazed [15]-[18] or made of glass blocks [19]) [20].

Glazed partitions are usually made as transom-mullion structures, in which the areas between the metal [21]-[23] or timber [24], [25] profiles are filled with matt or transparent special glazing with fire resistance properties [26]-[29]. Partitions of this type use mostly multi-layer glass units as glazing, with thermal breaks (fire resistant layers) or intumescent gel between the layers of tempered or semi-tempered glass. Behavior of monolithic and multi-layer glass panes in fire conditions are presented in Fig. 1 and 2 respectively.

a)

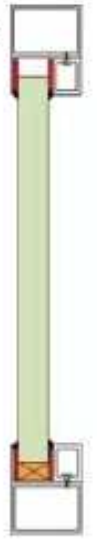

b)

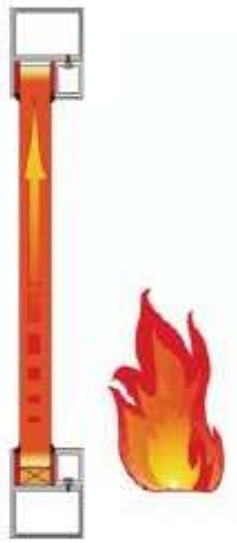

c)

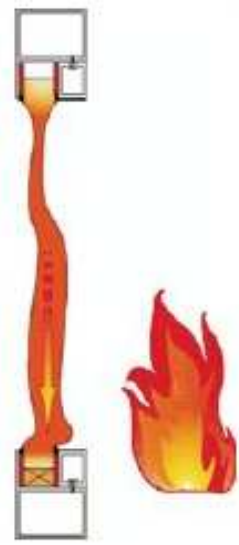

Fig. 1. Behavior of monolithic glass pane in fire: (a) prior to the fire; (b) after c.a. 10 minutes of fire, (c) after c.a. 30 minutes of fire [18] 
a)

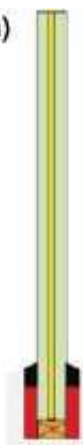

b)

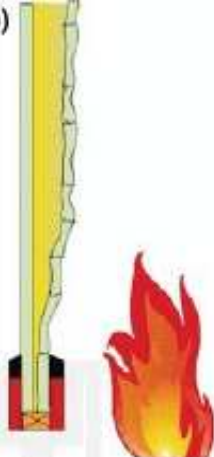

c)

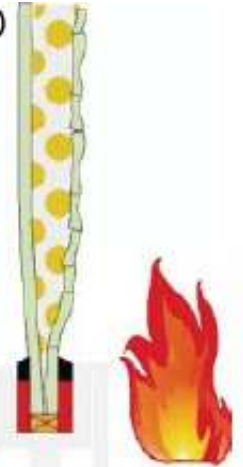

Fig. 2. Behavior of multi-layered glass pane in fire: (a) prior to the fire; (b) after c.a. 10 minutes of fire, (c) after c.a. 30 minutes of fire [18]

Profiles used in fire resistant glazed partitions usually have a symmetrical crosssection. The timber ones are made of solid or laminated wood. The metal profiles are composed of aluminium or steel elements connected with thermal separator (three-chamber profiles) [30]. In case of metal profiles, it is essential to proper fill in their section in order to ensure insulation of the profiles and reduce the adverse impacts of the thermal stress [31]. Inside the profiles there are placed special insulating inserts usually made of gypsum plasterboards, silicate - cement boards, silicate - calcium boards or mineral wool plates, although on the market are also present solutions with timber infill [32], [33].

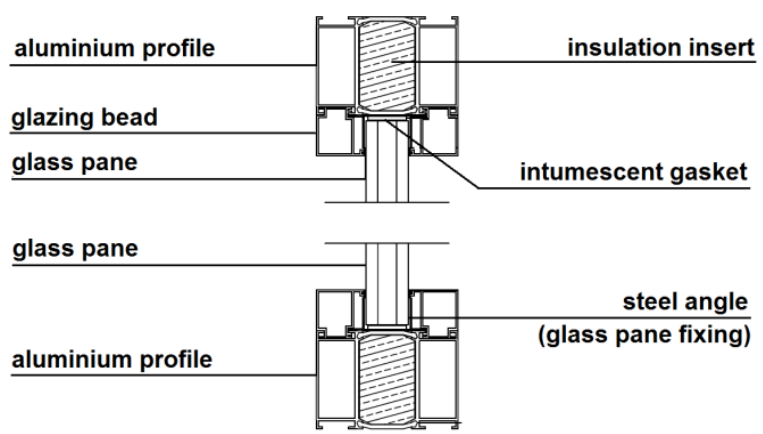

Fig. 3. Example of three-chamber profile cross-section [21]

The use of three-chamber profiles is a good solution from an economic point of view, because the same profiles can achieve different classes of fire resistance by changing the type or degree to which they are filled with fire resistant inserts or the size of thermal break between the sections (changing the cross-section of the central chamber).

An example of the cross-section of a three-chamber aluminium profile with a fixed glazing is shown in Fig. 3. The figure clearly shows intumescent gaskets 
between the profile and the glazing. Those elements, usually made on the base of expandable graphite [34], [35] increase their volume under high temperature and thus close the gaps that fire could use to get through.

Increasingly common in the market solution is "fully glazed partition" [36], [37] with structural connection of the glass panes. In this type of partitions aluminium profiles are used only along the perimeter of the partition, mullions are replaced by a special fireproof silicone or intumescent gaskets, and the transoms in most cases do not occur.

\section{FIRE RESISTANCE TESTS}

The glazed partition design or project does not give a clear answer on whether it will maintain fire integrity and insulation throughout the specific period, a fire resistance test must be performed.

According to the European Union provisions the partitions should be tested in accordance with EN 1364-1 [38] maintaining the procedures outlined in EN 1363-1 [39] and where appropriate EN 1363-2 [40]. The fire resistance test is carried out by providing heat on one side of the partition. In the case of the walls with a symmetrical cross-section option it is enough to check them only from one side and for non-symmetrical solutions it is necessary to test them from each side.

The test specimen is heated in accordance with the standard time-temperature curve (defined in formula 3.1 and presented by the solid line in Fig. 4), assumed as a characteristic for reflection of a fire inside a building (fully developed, following the flashover).

$$
T=345 \log _{10}(8 t+1)+20
$$

where:

$\mathrm{T}$ - average furnace temperature, in degrees Celsius,

$\mathrm{t}$ - time from the start of the test, in minutes.

During the glazed partition fire resistance test, the following performance criteria are checked:

- fire integrity (E),

- fire insulation (I),

- radiation $(\mathrm{W})$,

- resistance to mechanical impact (M). 
Fire integrity is the ability of glazed partition test specimen, when exposed to fire on one side, to prevent the passage through it of hot gases and flames and to prevent the occurrence of flames on the unexposed side.

Fire integrity is maintained if:

- the cotton pad does not ignite within a period of 30 seconds after it is applied to the test specimen,

- the penetration by means of a gap gauge with a width of $25 \mathrm{~mm}$, or $6 \mathrm{~mm}$ along $150 \mathrm{~mm}$, applied to the gap (created by the fire) is not possible,

- the flame is not sustained on the unheated side (no continuous fire lasting more than $10 \mathrm{~s}$ has appeared).

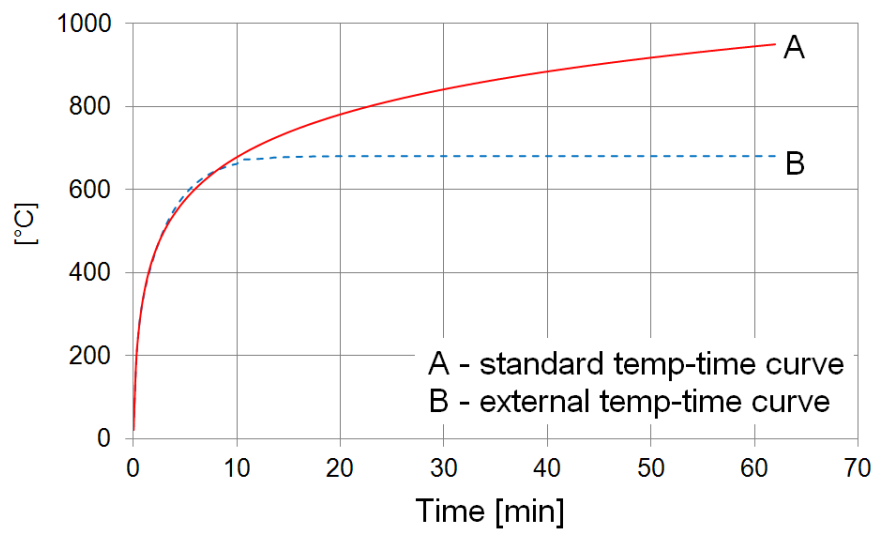

Fig. 4. Temperature-time curves, A - standard curve, B - external fire curve [41]

Figure 5 show the unexposed surface of specimens in which fire integrity has not been maintained for various reasons.

Fire insulation means the ability of certain test specimen that function as a separating part of the building structure and are subjected to fire on one side to limit the temperature rise on the unexposed surface above a given level.

The maximum and average temperature rises on the unexposed surface of the test specimen are checked with thermocouples attached to the test specimen by means of a temperature resistant adhesive[42]. The thermocouple scheme is shown in Fig. 6.

Radiation is the ability of a structural element to withstand fire applied on one side thereby limiting the probability of transferring the fire to adjacent materials as a result of significant heat radiation by the element or by its unheated surface. The measurement method is defined by the EN 1363-2 standard [40].

In the case of a fire, mechanical impacts resulting from damaging other structural elements or items exposed to the fire may influence the fire resistance 
of the partition. The resistance to mechanical impacts is checked by striking the partition with the so-called striking element (elliptical bag filled with lead shot). The striking element is suspended on a steel cable attached to a fixed point at the testing station and fitted in such a way that it touches the test specimen at the intended point of impact when stationary. The energy of the impact is obtained by the pendulous falling of the striking element (a pendulum with a length of $2750 \pm 50 \mathrm{~mm}$ - from the fixation point to the inside of the bag).
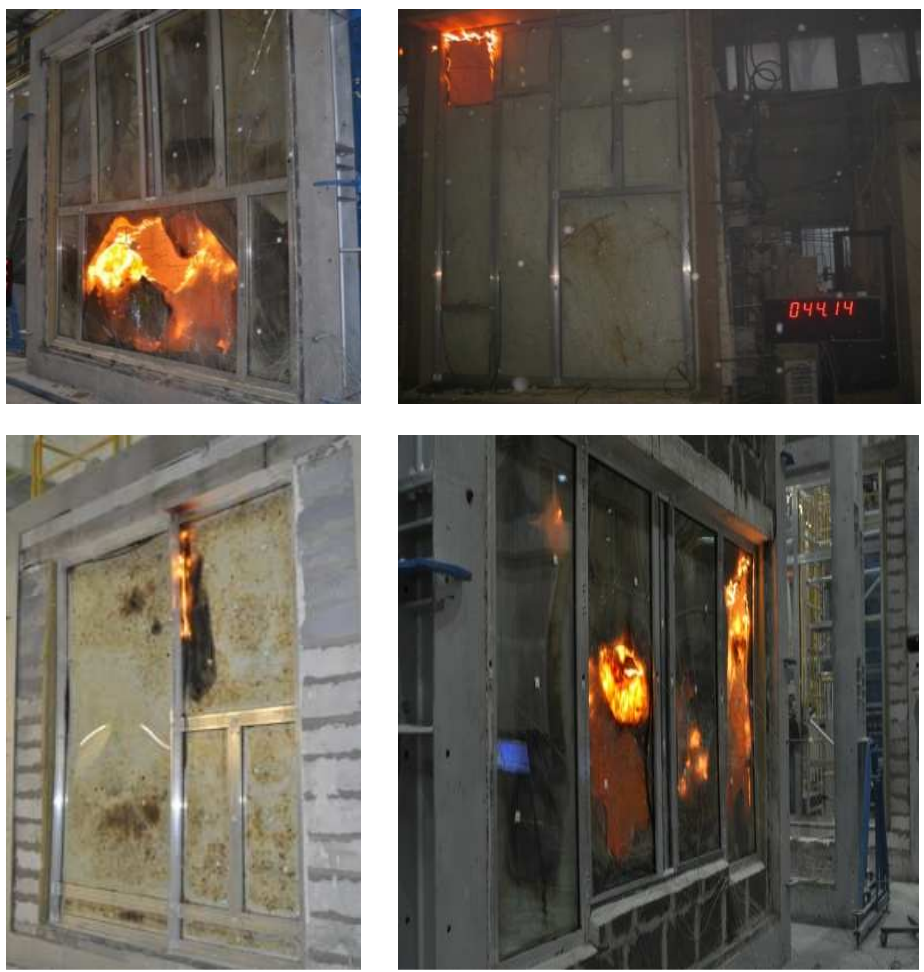

Fig. 5. Unexposed surface of tested specimens in the time of integrity failure [15]

Moreover, during the test deflection of the test specimen shall be measured although there are no performance criteria associated with it. The deflection of the test specimen may be important in determining the direct and/ or extended field of application of the test result [25].

Glazed partitions in practice are often equipped with the doorsets which also have to met the requirements connected with fire resistance and, in certain cases, smoke control. Testing of this type components is carried out according to a different standard. In this specific case, the doorset is a test specimen and glazed partition is only an associate (for fire resistance) or supplementary (in case of smoke control) supporting construction. Cases of this type and testing 
methodology in the field of fire resistance are presented in the articles [44]-[51], and in the field of smoke control in the articles [48], [49], [52]-[54].
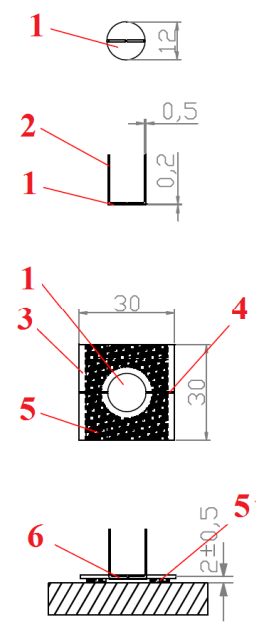

1 - copper disc,

2 - measuring system wire,

3 - insulating pad,

4 - incision to allow placement of the cap on the copper disc,

5 -example of the adhesive placement between the thermocouple and tested specimen,

6 - copper disc and insulating pad connected czone

with the test specimen

Fig. 6. Thermocouple scheme [43]

\section{GENERAL PRINCIPLES OF CLASSIFICATION}

Aluminium glazed partitions in European Union are classified in accordance with the EN 13501-2 [55] standard, and the fire resistance class is given based on testing conducted in accordance with EN 1364-1 [38].

The classification takes into account the performance criteria presented in p. 3, which are assessed in the following manner:

- fire integrity (E) - assessed on the basis of three aspects: ignition of the cotton pad, sustained flaming on the unexposed surface or gaps exceeding the permissible dimensions; the cotton pad inflammation criterion is not taken into account if the element is classified only for fire integrity without considering the fire insulation classification,

- fire insulation (I) - assessed on the basis of temperature rises on the unexposed surface of the test specimen (the average temperature rise is limited to $140^{\circ} \mathrm{C}$ above the initial average temperature, while the maximum temperature rise at any point in the tested partition is limited to $180^{\circ} \mathrm{C}$ above the initial temperature),

- radiation (W) - assessed based on the time in which the maximum value of the radiation measured in accordance with EN 1363-2 [40] does not exceed $15 \mathrm{~kW} / \mathrm{m}^{2}$,

- resistance to mechanical impact (M) - assessed (after reaching the required classification time) based on the time after which the specimen has 
withstood the impact in accordance with EN 1363-2 [40] without deterioration of its fire integrity and/or insulation performance.

Standard EN 13501-2 [55] for partitions defines the fire resistance classes shown in Table 1.

Table 1. Fire resistance classes [56]

\begin{tabular}{|c|c|c|c|c|c|c|c|c|c|}
\hline $\mathbf{E}$ & - & 20 & 30 & - & 60 & 90 & 120 & - & - \\
\hline EI & 15 & 20 & 30 & 45 & 60 & 90 & 120 & 180 & 240 \\
\hline EI-M & - & - & 30 & - & 60 & 90 & 120 & 180 & 240 \\
\hline EW & - & 20 & 30 & - & 60 & 90 & 120 & - & - \\
\hline
\end{tabular}

In the classification document of glazed partition, in addition to a detailed technical description of the element, should be a point referring to the field of application of test results, containing all changes possible to make in the design of the partition, which does not affect the reduction of its fire resistance properties. We can distinguish the direct field of application, which is presented in a testing standard [38] and extended field of application which is described in the EXAP standard [57]. Glazed partitions classification methodology, with possible extensions according to the EXAP standard [57] has been widely discussed in the articles [56], [58]-[61].

\section{A COMPARISON OF TEMPERATURE RISES DEPENDING ON THE DEGREE OF CHAMBER FILLING}

A comparison has been made for two aluminium glazed partitions of the same size and the same design. The partitions differ in the type of glass used and the degree to which the skeleton profile chambers were filled.

The profiles of the compared partitions were of the same size (the central chamber with a cross-section of $38 \times 42 \mathrm{~mm}$ in the case of the frame and mullions, $38 \times 22 \mathrm{~mm}$ in the case of transoms, external chambers with a crosssection of $20 \times 43 \mathrm{~mm}$ in the case of frame and mullions, and $20 \times 23 \mathrm{~mm}$ in the case of the transoms) with fire resistant inserts made of silicate-cement board. The test conducted on the partition with profiles filled only in the central chamber lasted 37,5 min (Test 1), whereas the test for the partition with profiles filled in all three chambers lasted 68 minutes (Test 2). Both tests ended due to the loss of fire integrity by the test specimen, which made it impossible to continue the tests as they posed a risk to the personnel and the test equipment. General view of tested specimens with location of thermocouples is presented in Fig. 7.

Figures 8 and 9 presents a comparison of temperature rises on the unexposed surface between the profiles with the central chamber filled in and with all three 
chambers filled in. The temperature rises were measured on the frame, mullions and transoms of the aluminium glazed partition in locations shown in Fig. 7.

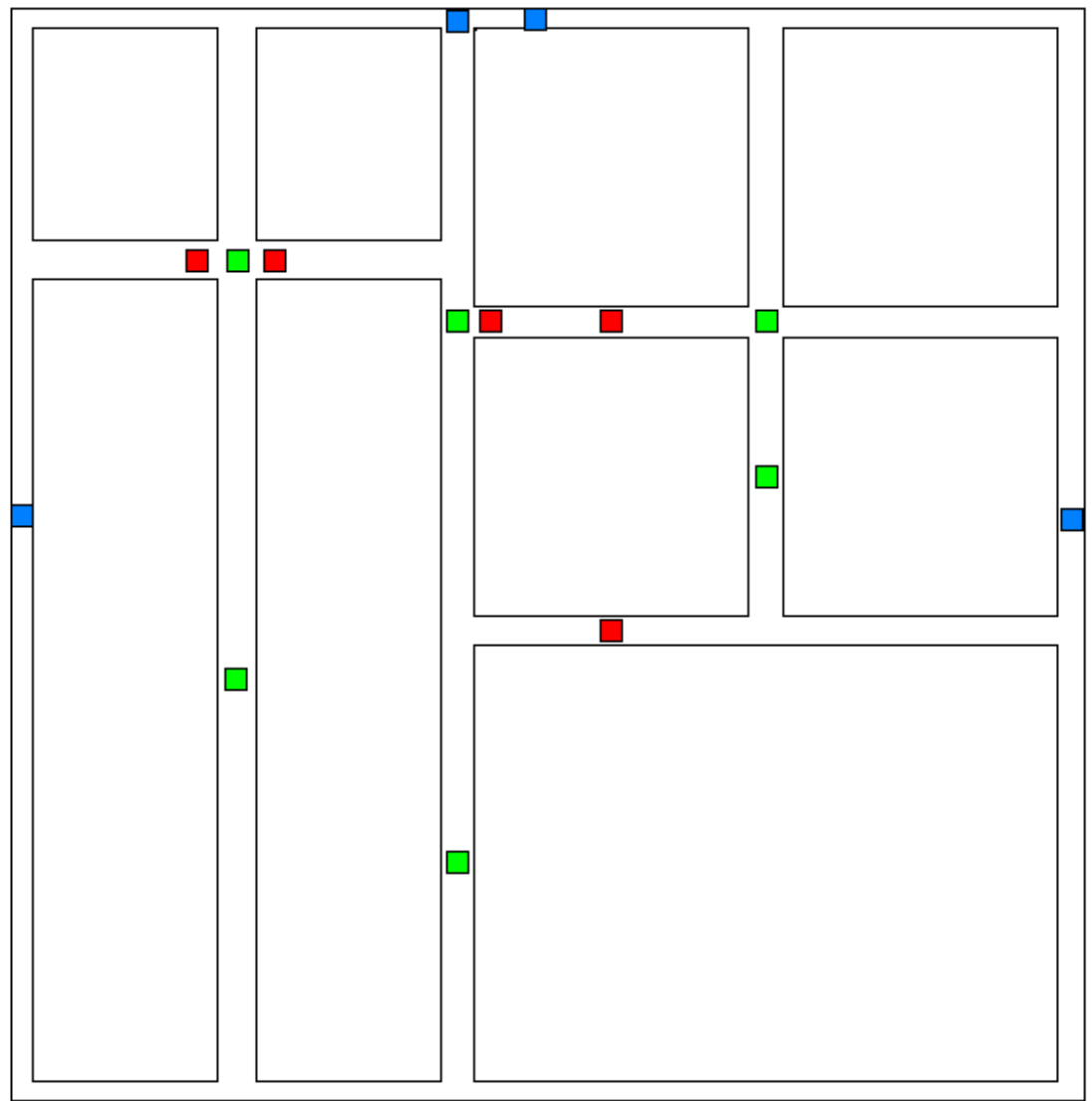

thermocouples for maximum temperature rise measurements on frame

$\square$ thermocouples for maximum temperature rise measurements on mullions

thermocouples for maximum temperature rise measurements on transoms

Fig. 7. General view of tested specimens with location of thermocouples

Figures $8 \mathrm{a}, 8 \mathrm{~b}$ and $9 \mathrm{a}$ shows comparisons of average temperature rise respectively on the mullions, frame and transoms (solid line represents the profiles with a fire resistant filling in the central chamber; dashed line represents the profiles with a fire resistant filling in all three chambers).

Fig. $9 \mathrm{~b}$ shows the difference between the average temperature rise on an unexposed surface of the profiles with the fire resistant filling only in the central chamber and the profiles with the fire resistant filling in all the chambers. 
The comparison was made also for the temperature rises on the glass panes. The results of this comparison are presented in the paper [62].

a)

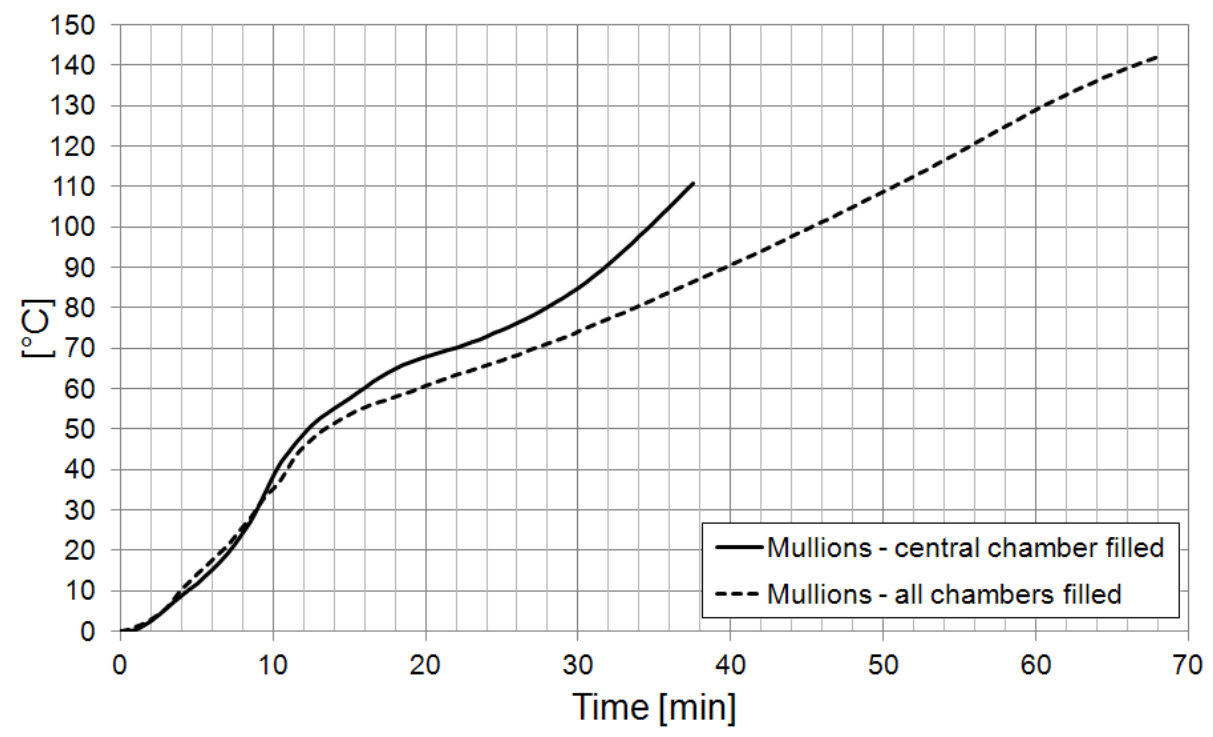

b)

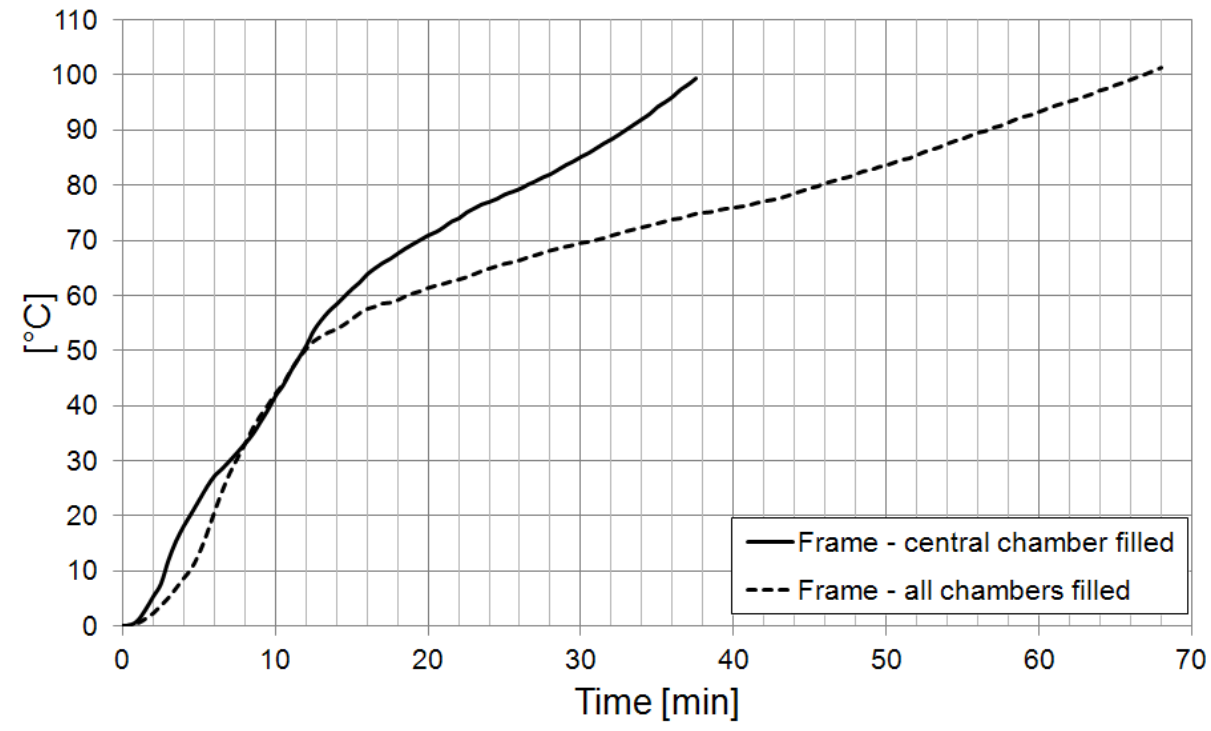

Fig. 8. The comparison of the average temperature rise on the: (a) mullions, (b) frame 
FIRE INSULATION OF ALUMINUM GLAZED PARTITIONS DEPENDING ON THE 101 INFILL SOLUTION OF FRAMEWORK PROFILES

a)

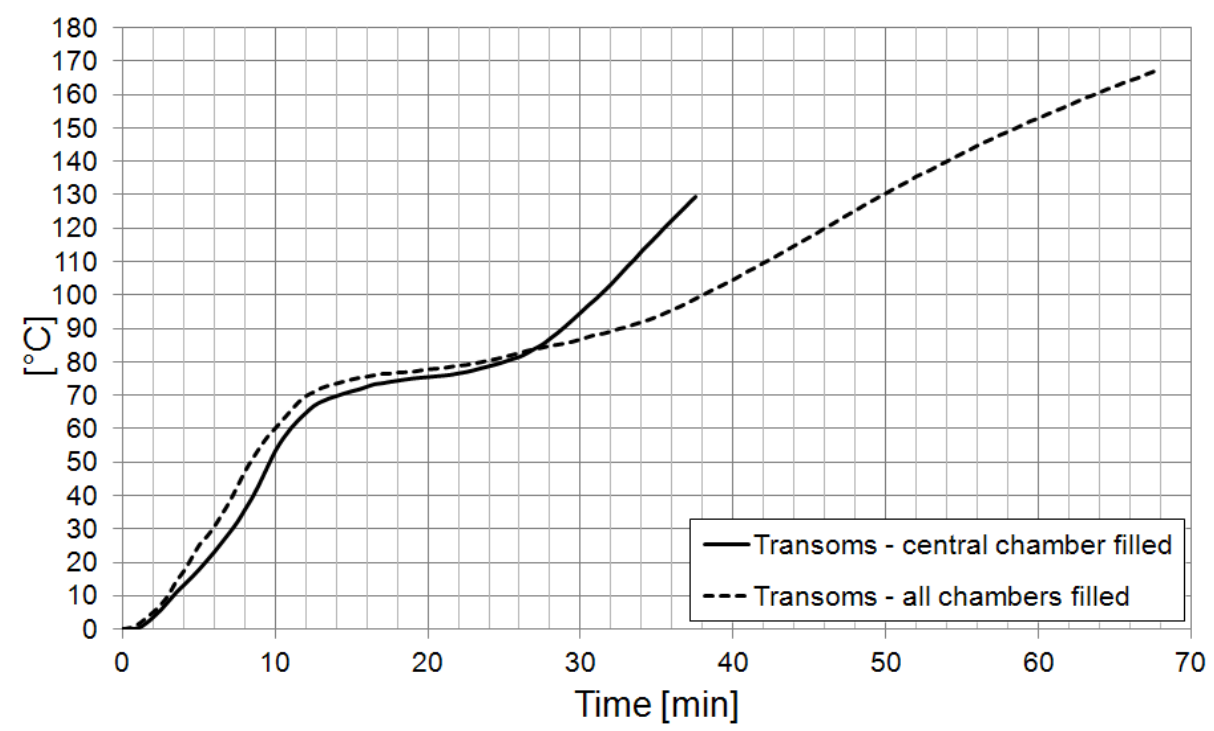

b)

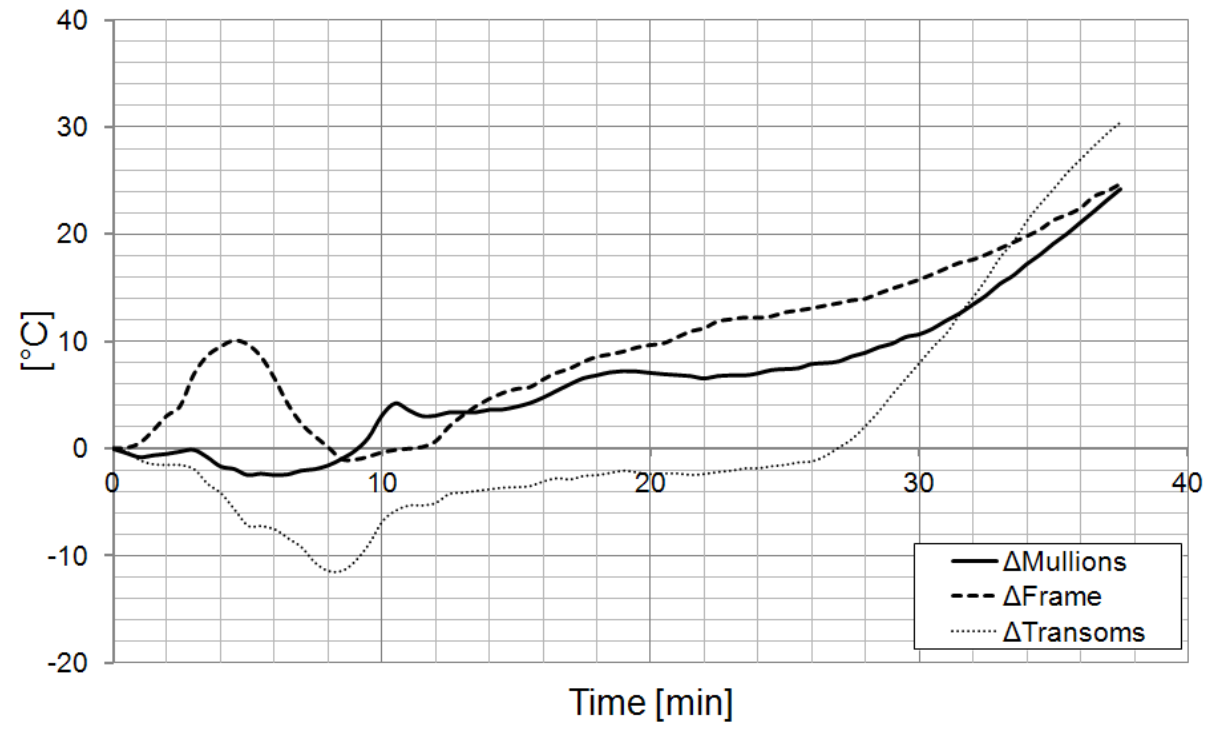

Fig. 9. (a) the comparison of the average temperature rise on the frame, (b) the difference between the average temperature rise on the unexposed surface of the profiles 


\section{CONCLUSIONS}

Analyzing the Fig. 8. and 9. it can be observed that the maximum value of the average temperature rise on the profiles with only the central chamber filled in, was achieved in 37,5'. In the case of profiles with all three chambers filled in, same temperature was achieved in 51', 66' and 49' respectively for mullions, frame and transoms. It shows that increasing the volume of insulation inserts have a major influence on the insulation properties of aluminium glazed partition profiles. The interesting fact is that in the beginning of the test for frame and transoms the temperature was greater on the profiles which were theoretically better insulated. This phenomenon may be related with the properties of insulation inserts, behavior of fire resistant glass or intumescent gaskets, however its full explanation requires future tests.

The fire resistance of the aluminium glazed partitions depends on multiple factors, such as: the type of applied skeleton profiles, insulating inserts in the profiles, and the degree to which the profile chambers are filled in, as well as the type of glass used, the size of the glass panes, the pane aspect ratio and the method of mounting the glazing.

Even a slight change in the structure of the partition can significantly reduce its fire resistance. For this reason, determining the actual fire resistance class of aluminium glazed partitions is only possible on the basis of test results from fire resistance tests performed on the test specimens taken from these partitions.

\section{REFERENCES}

1. R. A. Glass and A. I. Rubin, Fire safety for high-rise buildings," Gaithersburg, MD, 1979.

2. P. Sulik, B. Sędłak, P. Turkowski, and W. Węgrzyński, "Bezpieczeństwo pożarowe budynków wysokich i wysokościowych," in Budownictwo na obszarach zurbanizowanych, Nauka, praktyka, perspektywy, A. Halicka, Ed. Politechnika Lubelska, 2014, pp. 105-120.

3. S. Sassi, P. Setti, G. Amaro, L. Mazziotti, G. Paduano, P. Cancelliere, and M. Madeddu, "Fire safety engineering applied to high-rise building facades," MATEC Web Conf., vol. 46, p. 04002, May 2016.

4. G. Thomas, "Thermal properties of gypsum plasterboard at high temperatures," Fire Mater., vol. 26, no. 1, pp. 37-45, Jan. 2002.

5. B. Wróblewski and A. Borowy, "Płyty gipsowo-kartonowe - odporność ogniowa ścian nienośnych," Izolacje, vol. 10, 2010.

6. P. Roszkowski and P. Sulik, "Wooden stud walls - problems with regard to structural fire design according to PN-EN 1995-1-2," Ann. Warsaw Univ. Life Sci. - SGGW For. Wood Technol., vol. 87, pp. 181-185, 2014. 
7. P. Roszkowski, P. Sulik, and B. Sędłak, "Fire resistance of timber stud walls," Ann. Warsaw Univ. Life Sci. - SGGW For. Wood Technol., vol. 92, pp. 368-372, 2015.

8. N. Narayanan and K. Ramamurthy, "Structure and properties of aerated concrete: a review," Cem. Concr. Compos., vol. 22, no. 5, pp. 321-329, Oct. 2000.

9. T.-D. Nguyen, F. Meftah, R. Chammas, and A. Mebarki, "The behaviour of masonry walls subjected to fire: Modelling and parametrical studies in the case of hollow burnt-clay bricks," Fire Saf. J., vol. 44, no. 4, pp. 629-641, May 2009.

10. G. Zapotoczna-Sytek, P. Sulik, G. Woźniak, and M. Abramowicz, "Przegrody budowlane wykonane z autoklawizowanego betonu komórkowego (ABK), a bezpieczeństwo pożarowe," in Dni betonu: Tradycja i nowoczesność. 8 Konferencja, 2014, pp. 803-814.

11. M. R. E. Looyeh, K. Rados, and P. Bettess, "Thermochemical responses of sandwich panels to fire," Finite Elem. Anal. Des., vol. 37, no. 11, pp. 913927, Oct. 2001.

12. J. M. Davies, Lightweight sandwich construction. John Wiley \& Sons, 2008.

13. B. Wróblewski and A. Borowy, "Badanie i klasyfikacja w zakresie odporności ogniowej ścian i dachów z płyt warstwowych,” Izolacje, vol. 78, pp. 30-34, 2012.

14. P. Roszkowski and P. Sulik, "SANDWICH PANELS - BEHAVIOR IN FIRE BASED ON FIRE RESISTANCE TESTS,” Appl. Struct. Fire Eng., Jan. 2016.

15. B. Sędłak, "Systemy przegród aluminiowo szklanych o określonej klasie odporności ogniowej," ŚWIAT SZKŁA, vol. 18, no. 10, pp. 30-33,41, 2013.

16. A. Borowy, "Fire Resistance Testing of Glazed Building Elements," in POŽÁRNÍ OCHRANA 2014, 2014, pp. 15-17.

17. B. Sędłak, "Bezpieczeństwo pożarowe przeszklonych ścian działowych," ŚWIAT SZKŁA, vol. 20, no. 5, pp. 34-40, 2015.

18. Z. Laskowska and M. Kosiorek, "Bezpieczeństwo pożarowe ścian działowych przeszklonych - badania i rozwiązania," ŚWIAT SZKŁA, vol. 1, pp. 16-21, 2008.

19. B. Sędłak, "Ściany działowe z pustaków szklanych - badania oraz klasyfikacja w zakresie odporności ogniowej," ŚWIAT SZKŁA, vol. 19, no. 1, pp. 30-33, 2014.

20. P. Sulik and B. Sędłak, "Ochrona przeciwpożarowa w przegrodach wewnętrznych," Izolacje, vol. 20, no. 9, pp. 30-34, 2015.

21. B. Sędłak, J. Kinowski, D. Izydorczyk, and P. Sulik, "FIRE RESISTANCE TESTS OF ALUMINIUM GLAZED PARTITIONS, Results comparison," Appl. Struct. Fire Eng., Jan. 2016. 
22. B. Sędłak and P. Sulik, "Odporność ogniowa wielkogabarytowych pionowych elementów przeszklonych," Mater. Bud., vol. 1, no. 7, pp. 2830, Jul. 2015.

23. M. Kosiorek and Z. Laskowska, "Bezpieczeństwo pożarowe - część XV, Ogniochronne przegrody przeszklone,” Mater. Bud., vol. 1, pp. 117-119, 2007.

24. B. Sędłak, D. Izydorczyk, and P. Sulik, "Fire Resistance of timber glazed partitions," Ann. Warsaw Univ. Life Sci. - SGGW For. Wood Technol., vol. 85, pp. 221-225, 2014.

25. P. Sulik and B. Sędłak, "Odporność ogniowa drewnianych przeszklonych ścian działowych,” ŚWIAT SZKŁA, vol. 20, no. 3, pp. 43-48, 56, 2015.

26. M. Wu, W. K. Chow, and X. Ni, "Characterization and thermal degradation of protective layers in high-rating fire-resistant glass," Fire Mater., vol. 39, no. 1, pp. 26-40, Jan. 2015.

27. Z. Laskowska and A. Borowy, "Szyby w elementach o określonej odporności ogniowej," ŚWIAT SZKŁA, vol. 20, no. 12, pp. 10-15, 2015.

28. Y. Zhan, Z. Xia, W. Xin, and L. Hai-lun, "Application and Integrity Evaluation of Monolithic Fire-resistant Glass," Procedia Eng., vol. 11, pp. 603-607, 2011.

29. K. Zieliński, "Szkło ogniochronne," ŚWIAT SZKŁA, vol. 1, pp. 9-11, 2008.

30. K. Kuczyński, "Kształtowniki metalowe z przekładką termiczną," Mater. Bud., vol. 8, pp. 38-39, 2010.

31. A. S. Usmani, J. M. Rotter, S. Lamont, A. M. Sanad, and M. Gillie, "Fundamental principles of structural behaviour under thermal effects," Fire Saf. J., vol. 36, no. 8, pp. 721-744, 2001.

32. B. Sędłak, P. Sulik, and P. Roszkowski, "Fire resistance tests of aluminium glazed partitions with timber insulation inserts," Ann. Warsaw Univ. Life Sci. - SGGW For. Wood Technol., vol. 92, pp. 395-398, 2015.

33. B. Sędłak, D. Izydorczyk, and P. Sulik, "Aluminium glazed partitions with timber insulation inserts - fire resistance tests results depending on the type of used wood," Ann. Warsaw Univ. Life Sci. - SGGW For. Wood Technol., vol. 92, pp. 102-106, 2016.

34. G. Camino and S. Lomakin, "Intumescent materials," in Fire Retardant Materials, A. R. Horrocks and D. Price, Eds. Woodhead Publishing Limited, 2001, pp. 318-335.

35. M. Modesti, A. Lorenzetti, F. Simioni, and G. Camino, "Expandable graphite as an intumescent flame retardant in polyisocyanurate-polyurethane foams," Polym. Degrad. Stab., vol. 77, no. 2, pp. 195-202, Jan. 2002.

36. P. Sulik, B. Sędłak, and J. Kinowski, "Study on critical places for maximum temperature rise on unexposed surface of walls with butt jointed glazing test 
specimens," in IFireSS 2017 - 2nd International Fire Safety Symposium Naples, Italy, 2017.

37. B. Sędłak, "Bezszprosowe szklane ściany działowe o określonej klasie odporności ogniowej," ŚWIAT SZKŁA, vol. 19, no. 11, p. 24,26,28,30, 2014.

38. EN 1364-1:2015 Fire resistance tests for non-loadbearing elements - Part 1: Walls.

39. EN 1363-1:2012 Fire resistance tests. General requirements.

40. EN 1363-2:1999 Fire resistance tests. Alternative and additional procedures.

41. B. Sędłak and P. Sulik, "Odporność ogniowa pionowych elementów przeszklonych," Szkło i Ceram., vol. 66, no. 5, pp. 8-10, 2015.

42. P. Roszkowski and B. Sędłak, "Metodyka badań odporności ogniowej przeszklonych ścian działowych," ŚWIAT SZKŁA, vol. 16, no. 9, pp. 5964, 2011.

43. B. Sędłak, J. Kinowski, and P. Sulik, "Miejsca krytyczne elementów próbnych przeszklonych ścian osłonowych pod względem izolacyjności ogniowej," BiTP, vol. 45, no. 1, pp. 38-50, 2017.

44. D. Izydorczyk, B. Sędłak, B. Papis, and P. Turkowski, "Doors with Specific Fire Resistance Class," Procedia Eng., vol. 172, pp. 417-425, 2017.

45. D. Izydorczyk, B. Sędłak, and P. Sulik, "THERMAL INSULATION OF SINGLE LEAF FIRE DOORS, Test results comparison in standard temperature-time fire scenario for different types of doorsets," Appl. Struct. Fire Eng., Jan. 2016.

46. B. Sędłak, "Metodyka badań odporności ogniowej drzwi przeszklonych. Cz. 2.," SWIAT SZKŁA, vol. 17, no. 4, pp. 55-58,60, 2012.

47. B. Sędłak, "Metodyka badań odporności ogniowej drzwi przeszklonych. Cz. 1.," ŚWIAT SZKŁA, vol. 17, no. 3, pp. 50-52,60, 2012.

48. B. Sędłak and P. Sulik, "Badania odporności ogniowej i dymoszczelności drzwi przeszklonych zgodnie z wymaganiami normy wyrobu PN-EN 16034. Cz. 1," ŚWIAT SZKŁA, vol. 2, pp. 30-35, 2017.

49. B. Sędłak and P. Sulik, "Badania odporności ogniowej i dymoszczelności drzwi przeszklonych zgodnie z wymaganiami normy wyrobu PN-EN 16034. Cz.2," ŚWIAT SZKŁA, vol. 3, pp. 40,42-43, 2017.

50. D. Izydorczyk and P. Sulik, "Odporność ogniowa drzwi stalowych," Mater. Bud., vol. 1, no. 7, pp. 33-36, Jul. 2015.

51. P. Sulik and B. Sędłak, "Odporność ogniowa drzwi z dużymi przeszkleniami," ŚWIAT SZKŁA, vol. 20, no. 3, pp. 38-42, 2015.

52. B. Sędłak, A. Frączek, and P. Sulik, "Wpływ zastosowanego rozwiązania progowego na dymoszczelność drzwi przeciwpożarowych," Mater. Bud., vol. 1, no. 7, pp. 26-29, Jul. 2016. 
53. P. Sulik, B. Sędłak, and D. Izydorczyk, "Odporność ogniowa i dymoszczelność drzwi przeciwpożarowych na wyjściach awaryjnych z tuneli - badania i klasyfikacja," Logistyka, no. 6, pp. 10104-10113, 2014.

54. B. Sędłak, "Przeszklone drzwi dymoszczelne - badania oraz klasyfikacja w zakresie dymoszczelności," ŚWIAT SZKŁA, vol. 18, no. 4, pp. 35-38, 2013.

55. EN 13501-2:2016 Fire classification of construction products and building elements. Classification using data from fire resistance tests, excluding ventilation services.

56. B. Sędłak and P. Roszkowski, "Klasyfikacja w zakresie odporności ogniowej przeszklonych ścian działowych," ŚWIAT SZKŁA, vol. 17, no. 78, pp. 54-59, 2012.

57. EN 15254-4:2008+A1:2011 Extended application of results from fire resistance tests. Non-loadbearing walls. Glazed constructions.

58. J. Kinowski, B. Sędłak, P. Sulik, and D. Izydorczyk, "FIRE RESISTANCE GLAZED CONSTRUCTIONS CLASSIFICATION, Changes in the field of application,” Appl. Struct. Fire Eng., Jan. 2016.

59. Z. Laskowska and A. Borowy, "Rozszerzone zastosowanie wyników badań odporności ogniowej ścian działowych przeszklonych wg PN-EN 15254-4," Mater. Bud., vol. 7, pp. 62-64, 2012.

60. B. Sędłak and P. Sulik, "Badanie i klasyfikacja w zakresie odporności ogniowej przeszklonych ścian działowych zgodnie z wymaganiami nowego wydania normy badawczej. Cz. 2.," ŚWIAT SZKŁA, vol. 21, no. 5, pp. 2728, 30-34, 2016.

61. B. Sędłak and P. Sulik, "Badanie i klasyfikacja w zakresie odporności ogniowej przeszklonych ścian działowych według wymagań nowego wydania normy badawczej. Cz. 1.," ŚWIAT SZKŁA, vol. 21, no. 2, pp. 3840, 42, 2016.

62. B. Sędłak, "Badania odporności ogniowej przeszklonych ścian działowych," ŚWIAT SZKŁA, vol. 19, no. 2, pp. 30-33, 2014.

\section{IZOLACYJNOŚĆ OGNIOWA ALUMINIOWYCH PRZESZKLONYCH ŚCIAN DZIAŁOWYCH W ZALEŻNOŚCI OD SPOSOBU WYPEŁNIENIA PROFILI SZKIELETU}

\section{Streszczenie}

Ściana działowa jest rodzajem wewnętrznej ściany budynku i nie powinna przenosić innych obciążeń konstrukcyjnych niż ciężar własny. W przypadku obszaru dotyczącego bezpieczeństwa pożarowego powinny m.in. spełniać wymagania z zakresu odporności 
ogniowej, dotyczące kryteriów szczelności i izolacyjności. W artykule przedstawiono porównanie wyników badań w zakresie odporności ogniowej aluminiowych przeszklonych ścian działowych w przypadku różnego stopnia wypełniania profili ich szkieletu. Ponadto szeroko omówione zostały główne problemy związane z odpornością ogniową aluminiowych przeszklonych ścian działowych, w tym metodyka badań i sposób klasyfikacji elementów tego typu oraz stosowane w nich specjalne rozwiązania techniczne pozwalające na osiągnięcie wymaganych właściwości.

W Laboratorium Badań Ogniowych Instytutu Techniki Budowlanej przeprowadzone zostały dwa badania w zakresie odporności ogniowej aluminiowych przeszklonych ścian działowych o takich samych wymiarach i identycznym schemacie konstrukcyjnym, różniące się od siebie rodzajem zastosowanych przeszkleń oraz sposobem wypełnienia profili szkieletu (ilością zastosowanych wkładów izolacyjnych). Celem badania było porównanie izolacyjności ogniowej obu próbek.

Zarejestrowane wyniki przeprowadzonych badań pokazują wpływ sposobu wypełnienia profili szkieletu konstrukcyjnego na właściwości izolacyjne aluminiowych przeszklonych ścian działowych, w warunkach oddziaływania ognia i wysokiej temperatury.

Słowa kluczowe: ściana przeszklona, profile aluminiowe, wkłady izolacyjne, odporność ogniowa, szczelność ogniowa, izolacyjność ogniowa, bezpieczeństwo pożarowe

Editor received the manuscript:19.07.2017 